\title{
Microbial and metabolic profiling reveal strong influence of water table and land-use patterns on classification of degraded tropical peatlands
}

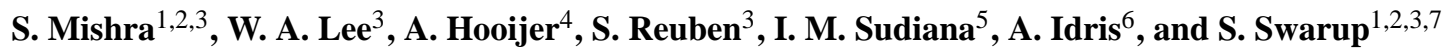 \\ ${ }^{1}$ Metabolites Biology Laboratory, Department of Biological Sciences, National University of Singapore (NUS), 117543, \\ Singapore \\ ${ }^{2}$ NUS Environmental Research Institute, NUS, T-Lab Building, 5A Engineering Drive 1, 117411, Singapore \\ ${ }^{3}$ Singapore-Delft Water Alliance Block E1, No 1 Engineering Drive 2, NUS, 117576, Singapore \\ ${ }^{4}$ Deltares, P.O. Box 177, 2600 MH Delft, the Netherlands \\ ${ }^{5}$ Cibinong Science Center, LIPI, Jl. Raya Bogor Km 46, Cibinong Bogor, 16911, Indonesia \\ ${ }^{6}$ Faculty of Agriculture, University of Jambi, Jambi, 36122, Indonesia \\ ${ }^{7}$ Singapore Centre on Environmental Life Sciences Engineering (SCELSE), 60 Nanyang Drive, NTU, 637551, Singapore \\ Correspondence to: S. Swarup (sanjay@nus.edu.sg)
}

Received: 21 July 2013 - Published in Biogeosciences Discuss.: 26 August 2013

Revised: 18 January 2014 - Accepted: 9 February 2014 - Published: 3 April 2014

\begin{abstract}
Tropical peatlands from southeast Asia are undergoing extensive drainage, deforestation and degradation for agriculture and human settlement purposes. This is resulting in biomass loss and subsidence of peat from its oxidation. Molecular profiling approaches were used to understand the relative influences of different land-use patterns, hydrological and physicochemical parameters on the state of degraded tropical peatlands. As microbial communities play a critical role in biogeochemical cascades in the functioning of peatlands, we used microbial and metabolic profiles as surrogates of community structure and functions, respectively. Profiles were generated from 230 bacterial $16 \mathrm{~S}$ rDNA fragments and 145 metabolic markers of 46 samples from 10 sites, including those from above and below water table in a contiguous area of $48 \mathrm{~km}^{2}$ covering five land-use types. These were degraded forest, degraded land, oil palm plantation, mixed crop plantation and settlements. Bacterial profiles were most influenced by variations in water table and land-use patterns, followed by age of drainage and peat thickness in that order. Bacterial profiling revealed differences in sites, based on the duration and frequency of water table fluctuations and on oxygen availability. Mixed crop plantations had the most diverse bacterial and metabolic profiles. Metabolic profiling, being closely associated with biogeochemical functions,
\end{abstract}

could distinguish communities not only based on land-use types but also their geographic locations, thus providing a finer resolution than bacterial profiles. Agricultural inputs, such as nitrates, were highly associated with bacterial community structure of oil palm plantations, whereas phosphates and dissolved organic carbon influenced those from mixed crop plantations and settlements. Our results provide a basis for adopting molecular marker-based approaches to classify peatlands and determine relative importance of factors that influence peat functioning. Our findings will be useful in peatland management by providing a basis to focus early efforts on hydrological interventions and improving sustainability of oil palm plantations by adopting mixed cropping practices to increase microbial diversity in the long term.

\section{Introduction}

Peatlands are formed by the accumulation of partially decayed vegetation matter over over millennial timescales in low-lying areas that are frequently waterlogged due to heavy rainfall or periodic inundation (Anderson, 1964). Peatlands are a highly vulnerable natural resource that cover 50-70\% of global wetlands (Finlayson et al., 1999) and sequester 
one-third of the world's soil carbon (Freeman et al., 2012). In southeast Asia, peatlands cover an area of nearly 25 million ha and store approximately $69 \mathrm{Gt}$ of carbon, which is $77 \%$ of all the tropical peatland carbon pool $(88.6 \mathrm{Gt})$, of which $65 \%$ (57.4 Gt of carbon) is in Indonesia itself, distributed within 23.4 million ha of peatland (Page et al., 2011). Carbon density is relatively high in tropical compared to temperate or boreal peatlands; this is largely a consequence of deeper peat layers in the former, with peat thickness up to $20 \mathrm{~m}$ (Page et al., 2002).

Southeast Asian peatlands are under threat from anthropogenic activities, predominantly due to drainage and deforestation for agriculture and human settlement purposes. Forest fires and biomass burning linked to land-use change exacerbate these threats. These fire events in Indonesia crossed all past records, hitting 371 in the Pollutant Standards Index (PSI) in Singapore, based on daily average, during the smog event that engulfed neighboring countries, such as Singapore and Malaysia (Schmaltz, 2013). Such land-use changes and hydrological interventions have resulted in a drastic decrease in peatland water tables, exposing the biomass sequestered in the peat to aerobic microbial oxidation. Of the total area of peatlands in Indonesia, at least 2.2 million ha have been converted to commercial oil palm plantations, which is expected to increase to 6.2 million ha by 2020 (Miettinen et al., 2012a). Interspersed within the plantations are small areas of temporary human settlements. In peninsular Malaysia and the islands of Sumatra and Borneo, some $60 \%$ of peat swamps had been partly or completely deforested by 2007 , usually accompanied by some form of drainage, and only $10 \%$ remained in pristine condition (Miettinen and Liew, 2010). In recent years, rapidly increasing peat carbon losses from drained peatlands in southeast Asia have been found to contribute significantly to global greenhouse gas emissions (Melling et al., 2005; Furukawa et al., 2005; Couwenberg et al., 2010). Estimates of net carbon losses and resultant $\mathrm{CO}_{2}$ emissions from peatland drained for agriculture range from 30-40 $\mathrm{tCO}_{2} \mathrm{ha}^{-1} \mathrm{yr}^{-1}$ (Murdiyarso et al., 2010; Hergoualc' $\mathrm{h}$ and Verchot, 2011) to as high as $70 \mathrm{tCO}_{2} \mathrm{ha}^{-1} \mathrm{yr}^{-1}$ (Couwenberg et al., 2010; Jauhiainen et al., 2012), excluding forest biomass losses, fire losses and peat organic matter losses in the initial years after drainage. Carbon losses from such emissions and through fluvial processes have led to tropical peatlands being transformed from carbon sinks to carbon sources (Moore et al., 2013). The oxidation of drained peat is causing rapid subsidence by disappearance of the surface layers in the peat (Kool et al., 2006; Couwenberg and Hooijer, 2013). In a recent study from the same region of Sumatra, peat was reported to subside at a rate of $5 \mathrm{~cm} \mathrm{yr}^{-1}$, of which $92 \%$ loss is due to oxidation and not compaction or plant respiration (Hooijer et al., 2012). Oxidation of organic matter has been shown using mesocosms of boreal peat to be due to stimulation of microbial growth, thereby causing the breakdown of organic matter and release of carbon dioxide in a biogeochemical cascade (Fenner and Freeman, 2011).
In most ecosystems, changes in land-use patterns impact both microbial diversity and their activity (Wardle et al., 1998; Ollivier et al., 2011; Putten 2012). Water table depth, which directly affects the oxygen levels in the peat layer (Lahde, 1969), is an important factor in shaping bacterial community structure. Water table depth also affects water stress, which has been shown to have direct and indirect influences on soil bacterial community composition (Fierer et al., 2003). While geochemical conditions affect microbial communities, they, in turn, affect their environment. Therefore, it is important to study microbial community composition. Molecular profiling approaches have been widely used to describe microbial diversity in soil, rhizosphere, extreme environments, freshwater and mangrove ecosystems (Bai et al., 2012; Chan et al., 2013; He et al., 2012; Nold et al., 2000; Xiong et al., 2010). Microbial profiling approaches that are now widely used mainly rely on DNA fingerprinting (Zhou, 2003; Nocker et al., 2007; Nazaries et al., 2013) or on pyrosequencing of ribosomal DNA region (Chistoserdova, 2010; He et al., 2010). More recently, metabolic profiling has also emerged as a useful approach to report status of microbial functions in soil (Bundy et al., 2009) and rhizosphere (Lee et al., 2013). Two recent studies of intact, forested peatlands from Thailand (Kanokratana et al., 2011) and Malaysia (Jackson et al., 2009) used pyrosequencing and fingerprinting approaches to describe their microbial diversity and functional properties, respectively. They demonstrated the capability of such techniques to show broad phylogenetic diversity and genetic potential to degrade biomass, respectively.

In degraded temperate peatlands, i.e., those peatlands that have undergone massive land-use change due to drainage and deforestation, much is known about the relationship of microbial diversity to peatland functioning and greenhouse gas emissions (Opelt et al., 2007; Ausec et al., 2009; Kim et al., 2012; Tveit et al., 2013). In contrast, for tropical peatlands, we have a relatively poor understanding of the relationship of microbial diversity and factors influencing community structure for intact as well as tropical peatlands under land-use change. Given both the ecological and economic importance of these peatlands, it will be useful to understand the differences among various land-use patterns in degraded tropical peatland with respect to microbial ecology. Towards this direction, it is critical to develop scientific methods to manage the rapid change in land use from pristine conditions of peatlands and monitor the progress as well as effectiveness of ecosystem restoration interventions. In conjunction with existing methods, such as field surveys of flora and fauna of tropical peatlands that are undergoing land-use change (Posa et al., 2011), these combined approaches need to be adopted to classify peat in order to conserve remaining pristine peatlands. Our approach is based on the ability of molecular profiling to capture shifts in community structure and metabolic profiling to reflect the functional outcome of metabolic activities of microbes, plant roots and their exudates, respectively. Using these two microbial profiling approaches, we report 
the effects of water table depth and oxygen availability, landuse patterns, age of drainage and peat thickness on bacterial diversity in degraded peatlands of Indonesia. We focus on five land-use patterns from a contiguous study site: (a) degraded forest, which includes drained and heavily deforested peat swamp forest; (b) degraded land, which includes deforested and drained peatlands that have yet to undergo conversion for agricultural use; (c) oil palm plantation, which includes peatland area under palm plantations; (d) settlements, which includes peatland area under palm plantations interspersed with human settlements; and (e) mixed crop plantation, which includes peatland area under palm plantations, pineapple and tapioca. In order to determine importance of various management practices of these peatlands on the structure and functioning of the bacterial communities, we studied the influences of 11 physicochemical parameters. Based on our findings reported here, we make recommendations that will help in the classification, improved management and sustainability of tropical peatlands.

\section{Materials and methods}

\subsection{Site description and sampling}

The study area is located in peatlands of the eastern part of Jambi province, Sumatra, Indonesia (Fig. 1). Forested tropical peatlands are extensive in this area and a variety of landuse patterns are present due to land intensification activities. Land-cover classification was performed using visual image interpretation and manual on-screen delineation of land-cover polygons. The classification scheme was mainly based on variation in physical vegetation characteristics (e.g., height, sparseness, etc.) and included the main phases of the tropical peatland conversion and degradation processes (Miettinen et al., 2012b). The Landsat image and base maps of field sites were obtained from the University of Jambi, Jambi, Indonesia. The coordinates of monitoring sites were recorded using handheld global positioning system (GPS) devices. The coordinates of these sites were inserted onto the base maps using ArcView and ArcMap programs (ArcGISEsri, CA, USA).

The overall mapped area in the eastern part of Jambi comprised a total of $3390 \mathrm{~km}^{2}$ (Fig. 1), out of which water/seasonal water comprised $11 \mathrm{~km}^{2}$, or $0.3 \%$ of total mapped area. The land-cover classes used in Miettinen et al. (2012b) were regrouped and reclassified for this study. The land cover comprising (1) slightly and moderately degraded peat swamp forest (PSF) $\left(1656 \mathrm{~km}^{2}\right.$, or $49 \%$ of total mapped area) was classified as "intact PSF"; (2) heavily degraded PSF and secondary forest $\left(543 \mathrm{~km}^{2}\right.$, or $\left.16 \%\right)$ was classified as "degraded forest"; (3) shrubs, fern/grass and clearance area $\left(712 \mathrm{~km}^{2}\right.$, or $\left.21 \%\right)$ was classified as "degraded land"; (4) commercial plantations $\left(279 \mathrm{~km}^{2}\right.$, or $\left.8 \%\right)$ was classified as "oil palm plantation" or "mixed crop plan- tation", depending on land cover in that area; and (5) small holder mosaic and built-up areas $\left(188 \mathrm{~km}^{2}\right.$, or $\left.6 \%\right)$ was classified as "settlements". For this study, the contiguous landuse types were chosen that were present in Site A and Site B. Intact PSF was not included in this study because of being non-contiguous.

The coordinates of sampling locations distributed across two broad areas, referred to as Site A and Site B, were $103^{\circ} 53^{\prime} 52.58^{\prime \prime} \mathrm{E}, 1^{\circ} 43^{\prime} 12.47^{\prime \prime} \mathrm{S}$ and $103^{\circ} 49^{\prime} 32.23^{\prime \prime} \mathrm{E}$, $1^{\circ} 40^{\prime} 58.24^{\prime \prime} \mathrm{S}$, respectively (Fig. 1). The total areas covered by the sites were 42 and $6 \mathrm{~km}^{2}$, respectively. Out of five land-use patterns, degraded land with similar peat physical, geological and hydrological conditions was present in both Site A and Site B (Fig. 1). All study sites (Fig. 1) have been affected by fire in the past. The only exception is the degraded forest (DHFN: Deep peat depth, High water table, Degraded Forest and New drainage $<10$ years; please refer to legends of Fig. 1 for acronyms of site description). The fire events have occurred in the past in degraded land (DHAN) in Site A and B in 2004 and 2005, respectively. Burning occurred in oil palm and mixed crop plantation sites in Site B (MHPN, DHPN, MHXN and SHXN) in 2004, sites with oil palm plantations in Site A in low water table depth (MLPO) in 2001, and sites in oil palm plantations (DHPO) and in settlements (DHTO) in 2000. As part of routine management practices, fertilizers are applied to the sites that fall within oil palm and mixed crop plantations. The main categories of fertilizer are nitrogen-phosphorus-potassium (NPK 16:16:16) and urea, which are applied three times a year, and potassium chloride $(\mathrm{KCl})$, which is applied once a year.

In order to monitor the hydrological parameters, both rainfall and water table depths were measured periodically using rain gauges at strategic locations and dipwells in each transect. The dipwells consisted of perforated PVC pipes anchored into peat, reaching the mineral subsoil. These dipwells were used to monitor water table depth changes every two weeks, since 2009. Rainfall measurements were monitored on a daily basis. Average water table depths and total rainfall were calculated for every month. Data from August 2009 to August 2010 are being reported in this study. Sampling was performed in March 2010, preceding which the highest monthly rainfall $(370 \pm 25 \mathrm{~mm})$ in the period studied was recorded in February 2010.

At each sampling location, a $1 \mathrm{~m}^{3}$ pit was dug. Three equidistant pits were used for sampling in each transect. These transects ranged between 120 and $550 \mathrm{~m}$ at different sampling locations. We took samples at a predetermined distance from the water table along the wall of the pit. At this distance, we reached horizontally $10 \mathrm{~cm}$ into the peat to collect least disturbed samples. This process was repeated for each of the four walls of the pit at the same distance from the water table. A composite was then prepared using these four samples. The number of specified distances in sampling varied according to the water table depths in 


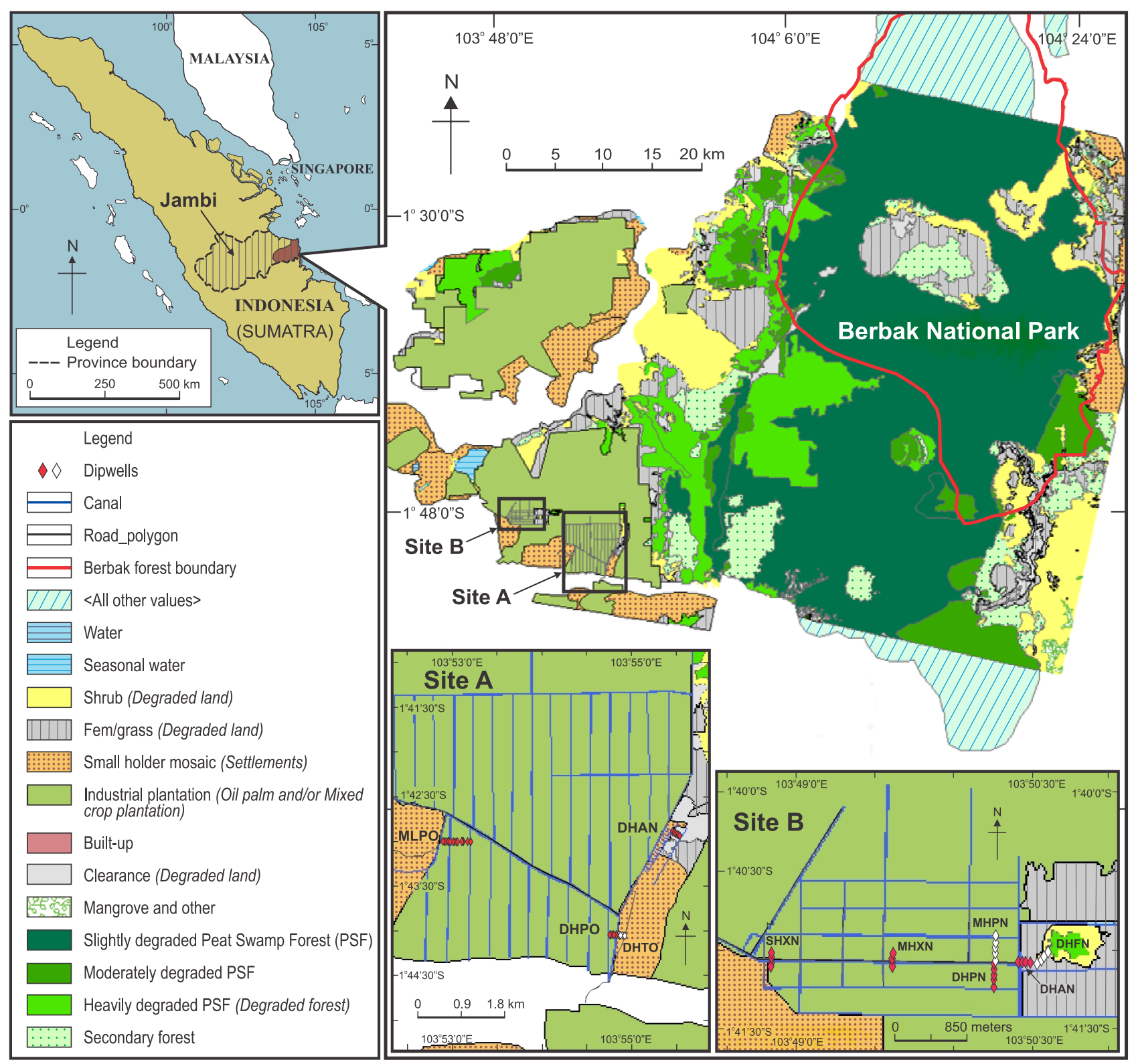

Fig. 1. Map showing Sumatra Island in Indonesia (top left) and land cover present in the eastern part of Jambi province (right). Study sites in this region of Jambi, Site A and Site B, are located at geographical locations $103^{\circ} 53^{\prime} 52.58^{\prime \prime} \mathrm{E}, 1^{\circ} 43^{\prime} 12.47^{\prime \prime} \mathrm{S}$ and $103^{\circ} 49^{\prime} 32.23^{\prime \prime} \mathrm{E}$, $1^{\circ} 40^{\prime} 58.24^{\prime \prime} \mathrm{S}$, respectively. Abbreviations are as follows: D, deep peat thickness ( $\left.>7 \mathrm{~m}\right)$; M, medium peat thickness $(3-7 \mathrm{~m}) ; \mathrm{S}$, shallow peat thickness $(<3 \mathrm{~m})$; H, high water table $(0-45 \mathrm{~cm})$; L, low water table $(>45 \mathrm{~cm})$; F, degraded forest; A, degraded land; P, oil palm plantations; $\mathrm{T}$, settlements; $\mathrm{X}$, mixed crop plantations; $\mathrm{N}$, drainage ( $<10$ years); $\mathrm{O}$, drainage ( $>10$ years). Land-use patterns described in this study are indicated within brackets in italics in the legend box above.

different sites. Samples using the above mentioned strategy were collected at a distance of $20-30 \mathrm{~cm}$ above water table (AWT) and from $20-30 \mathrm{~cm}$ below water table (BWT) in sterile $50 \mathrm{~mL}$ tubes from all sites, with exceptions at 4 sites. At three oil palm plantation sites in the MLPO transect (Fig. 1), the water table was extremely low $(80 \mathrm{~cm}$ below peat surface level); hence samples were collected from $20-30 \mathrm{~cm}$ and $50 \mathrm{~cm}$ AWT, respectively. One location within a mixed crop plantation was flooded; hence, only one sample was collected BWT and none from the AWT position. Peat water samples for metabolic profiling were collected from dipwells adjacent to each pit. All samples were shipped on ice to the laboratory and processed immediately. In order to analyze the oxygen availability at each sampling point, an OX-N Clark-type oxygen sensor (Unisense, Aarhus, Denmark) was used and data were recorded manually 


\subsection{Bacterial community structure (terminal restriction fragment length polymorphism (T-RFLP) analysis)}

Bulk peat gDNA was extracted using a ZR Soil Microbe DNA MidiPrep ${ }^{\mathrm{TM}}$ extraction kit (Zymo Research Corporation, Irvine, USA) based on the manufacturer's protocol, with minor modifications. The extracts were quantified spectrophotometrically (Nanodrop ND-1000, Nanodrop Technologies, Wilmington, DE, USA). Bacterial 16S rRNA genes were amplified using universal primer, BSF517-GCCAGCAGCCGCGGTAA and BSR1541/20AAGGAGGTGATCCAGCCGCA (Wilmotte et al., 1993). For T-RFLP analysis, forward primer was labeled with 6-carboxyfluorescein (FAM) at the $5^{\prime}$ end and reverse primer was labeled with photo-induced electron transfer (PET) at the $3^{\prime}$ end. PCR was performed in triplicate $(50 \mu \mathrm{L}$ reaction) using $50 \mathrm{ng}$ of template DNA and the following parameters: initial denaturation at $95^{\circ} \mathrm{C}$ for $10 \mathrm{~min}$, followed by denaturation $95^{\circ} \mathrm{C}$ for $1 \mathrm{~min}$, annealing at $58^{\circ} \mathrm{C}$ for $30 \mathrm{~s}$, extension at $72^{\circ} \mathrm{C}$ for $1 \mathrm{~min}$ and final extension at $72^{\circ} \mathrm{C}$ for $7 \mathrm{~min}$. Agarose gel electrophoresis, followed by staining of products with SYBR Green (Invitrogen, USA) was performed to check amplified product size and concentration. Amplicons from three replicates of PCR were pooled and cleaned up using NucleoSpin ${ }^{\circledR}$ Extract II according to the manufacturer's instructions. Five hundredng of each amplicon were digested with restriction enzymes Alu $I$ and Bsu RI (Fermantas) at $37^{\circ} \mathrm{C}$ for $16 \mathrm{~h}$. Digests were then purified using the NucleoSpin ${ }^{\circledR}$ Extract II kit, and an aliquot of $1 \mu \mathrm{L}$ was mixed with $8.5 \mu \mathrm{L}$ HiDi formamide (Applied Biosystems, Foster City, CA, USA) and $0.5 \mu \mathrm{L}$ of internal size standard (Applied Biosystems) for T-RFLP reactions. The labeled terminal-restriction fragments (TRFs) were detected on an ABI 3730XL automatic DNA sequencing machine (Applied Biosystems) in the GeneScan mode. For data collection from the DNA sequencing machine, GeneMapper software (Applied Biosystems) was used to compare relative lengths of TRFs with the internal size standard. For profile comparison, minimal and maximal cut-offs of 50 and $600 \mathrm{bp}$, respectively, were set and fragments with peak height below 75 were removed as filter noise.

\subsection{Chemical analysis}

Five grams of peat were mixed with $40 \mathrm{~mL}$ of analytical grade water. The mixture was shaken at $200 \mathrm{rpm}$ overnight to obtain a bioavailable extract for microorganisms from peat (Reynolds and Clarke, 2008). These extracts were used for analysis of total dissolved organic carbon (DOC) and inorganic carbon using a total organic carbon analyzer (TOC-V CPH E200V 220V, Shimadzu). Aliquots from the same remaining extracts were also analyzed for anions such as fluoride, chloride, nitrite, nitrate, phosphate, sulfate and cations such as sodium, ammonium, potassium, magnesium, and calcium using an ion chromatography analyzer (ICS-5000, Dionex).

Peat water samples were run through a Solid Phase Extraction cartridge using an Oasis ${ }^{\circledR}$ HLB cartridge $(1 \mathrm{cc} / 30 \mathrm{mg}$; $30 \mu \mathrm{m}$, Waters, USA) in order to extract, concentrate and clean up the metabolites (Parab et al., 2009). The samples were analyzed using ultra-performance liquid chromatography (UPLC) in a Waters ACQUITY UPLC ${ }^{\mathrm{TM}}$ system (Waters Corp., MA, USA), equipped with a binary solvent delivery system and an autosampler. The chromatography was performed on a Waters ACQUITY $C_{18} 1.7 \mu \mathrm{m}$ column $(100 \times 2.1 \mathrm{~mm})$. Mass spectrometry was performed based on MS conditions using a mass spectrometer equipped with an electrospray ionization source (UPLC-TOF-Bruker Daltonics). Data were extracted using Bruker Daltonics profile analysis software.

\subsection{Data analysis}

To analyze the variation in bacterial community structure as well as difference in metabolic functions, due to influence from analyzed parameters (namely, water table, land-use patterns, age of drainage and peat thickness), multivariate statistical techniques (PRIMER 6, PRIMER-E, Ltd., Plymouth, United Kingdom) were used to calculate distance matrices using Bray-Curtis similarity indices and one-way ANOSIM (Analysis of Similarity) coefficients (Legendre and Legendre, 1998). Unconstrained ordination plots with 100 iterations using nonmetric multidimensional scaling (nMDS) based on Bray-Curtis similarity were used to represent the outcome (Kruskal 1964, Shepard 1962). To analyze the relative influence of different parameters over bacterial communities, two-way ANOSIM (Clarke, 1993) was used. The global R statistic value (generated using one-way or twoway ANOSIM) indicates the degree of separation between the two communities, with values close to unity indicating more separation and a zero value indicating no difference between the groups.

To analyze influences of geochemical traits on the bacterial community structure, CCA (Canonical Correspondence Analysis) was performed using Canoco (version 4.5 for Windows, PRI Wageningen, the Netherlands) (Lepš and Šmilauer, 2003). Presence/absence of TRFs was used as "species" data. Geochemical data (anions, cations, DOC and inorganic carbon) were included in the analysis as "environmental" variables. Ordination biplots approximating the weighted differences between the individual communities (TRFLP patterns) with respect to each of the geochemical factors (represented as arrows) were drawn. The relative importance of geochemical factors in explaining variation in the bacterial T-RFLP profiles was explained by the length of the corresponding arrows, and the angle between arrows indicated the degree to which they were correlated. The impact of geochemical variables over bacterial community structure 
was calculated using a Monte Carlo permutation test based on 1000 random permutations (Rasche et al., 2011).

To predict the phylogeny of the bacterial species at the taxa level from the TRFs of $16 \mathrm{~S}$ rDNA, Fragment Sorter Suite (FRAGSORT) (ver. 5.0; Agricultural Research and Development Center, Ohio State University) and Phylogenetic Assignment Tool (PAT) (Kent et al. 2003) were used, adopting the methodology described in Lefebvre et al. (2010). Microbial Community Analysis (MiCA) - a virtual digest program (Shyu et al., 2007) - was used to construct a reference database for each set of primers.

\subsection{Clone library sequencing of $16 \mathrm{~S}$ rDNA gene}

In order to validate the presence of predicted species evaluated from FRAGSORT analysis, a clone library using $16 \mathrm{~S}$ rDNA from two randomly chosen sites that differed in water table, land-use pattern and oxic conditions was prepared. The sites chosen belong to settlements with high water table and oil palm plantations with low water table. The samples were taken from both oxic and anoxic zones of settlements and only from oxic zones of oil palm plantation sites.

The cleaned PCR product (using same non-labeled primer sequences as described earlier) of $16 \mathrm{~S}$ rDNA from settlements and oil palm plantation sites was cloned into 3956 bp pCR ${ }^{\circledR} 4-\mathrm{TOPO}^{\circledR}$ vector using TOPO TA Cloning kit for sequencing (Invitrogen, USA) according to the manufacturer's protocol. One Shot ${ }^{\circledR}$ TOP 10 Competent Cells (Invitrogen, USA) was used in order to transform the recombinant plasmid. DNA Sequencing was performed on a DNA sequencer (ABI 3130 Genetic Analyzer) using forward or reverse M13 primers, on plasmid DNA extracted using Wizard $^{\circledR}$ Plus SV MiniPrep DNA Purification System (Promega, USA) from individual clones. DNA sequence data were analyzed as described previously (Reuben et al., 2012). Briefly, sequences were trimmed and edited using MEGA5 (Tamura et al., 2011). MAFTT (Katoh et al., 2009) was used for aligning the sequences and identifying reverse orientation. Sequences were then reverse-complemented using MEGA5. Vector contamination was checked using the vector screening tool in Sequin (http://www.ncbi.nlm.nih.gov/ Sequin/sequin.hlp.html), and a chimera check was performed using Bellerophon (Katoh et al., 2009) followed by Mallard 1.2. (Ashelford et al., 2006). Sequences of 302 clones were submitted to GenBank, and the nucleotide sequence data reported in this paper are published in the GenBank nucleotide database under accession numbers JF739556-JF739857.

\section{Results}

\subsection{Influences of peat characteristics on bacterial community structure}

\subsubsection{Oxygen availability and water table}

Oxygen availability was lower in the BWT samples compared to AWT samples by a factor of three or more (Fig. 2a). The BWT oxygen levels were similar across all land-use types. Based on this, henceforth, we use the terms "oxic" and "anoxic" conditions to refer to oxygen availability in AWT and BWT zones, respectively. Effects of oxygen levels on bacterial DNA profiles were analyzed (Fig. $2 \mathrm{~b}$ ). In the ordination plot, samples from the low-water-table sites (across all oil palm plantations) tended to cluster together, regardless of oxic and anoxic zones. The remaining samples clustered roughly into oxic and anoxic zones, although samples from degraded land from anoxic zones were mixed within oxic zones. BWT points found within AWT group are of two types. One of these BWT groups is in a cluster that is highly influenced by low water table (as shown in Fig. 2b). This explains why this subgroup has both AWT and BWT points all coming from low-water-table sites. Of the remaining 8 BWT points within the AWT group, 3 belonging to oil palm plantation sites are right at the periphery of the BWTspecific group. Another one sample (marked by arrow) is an outlier which was due to flooding. This leaves 4 BWT points belonging to degraded land, which we believe have high water table fluctuations as the water table is not controlled by hydrological interventions. While forested areas are also not managed, they are unlikely to have large fluctuations due to closed canopy. Thus, the degraded forest BWT point falls in the BWT specific group. Anoxic zones supported more complex bacterial communities than oxic zones, although this was not the case for samples from degraded land (Table 1). The $\mathrm{pH}$ values measured from all sites did not show any significant correlation with Shannon diversity indices from different land-use types at both oxic and anoxic zones.

Continuous monitoring of the water table and rainfall revealed that variation in water table over the period (August 2009-August 2010) was influenced by rainfall in that period, with maximal rainfall in February 2010 of $370 \pm 25 \mathrm{~mm}$, averaged over all sites (Fig. 3a). Sampling was performed during the time when water table was highest in the entire period under study. Variation in the water table pattern was similar for all sites (DHFN, DHPO, DHAN, DHTO, SHXN, MHXN, DHPN and MHPN) except for five oil palm plantation sites (MLPO) that had low water table $(>50 \mathrm{~cm})$. The water table in sites with high water table depths fluctuated from -0.1 to $-0.7 \mathrm{~m}$ in the period under study. However, these fluctuations ranged from -0.75 to $-1.6 \mathrm{~m}$ in the sites with low water table depths in the same period, hence exposing the low-water-table sites to different durations of oxic and anoxic regimes compared to high-water-table sites. 


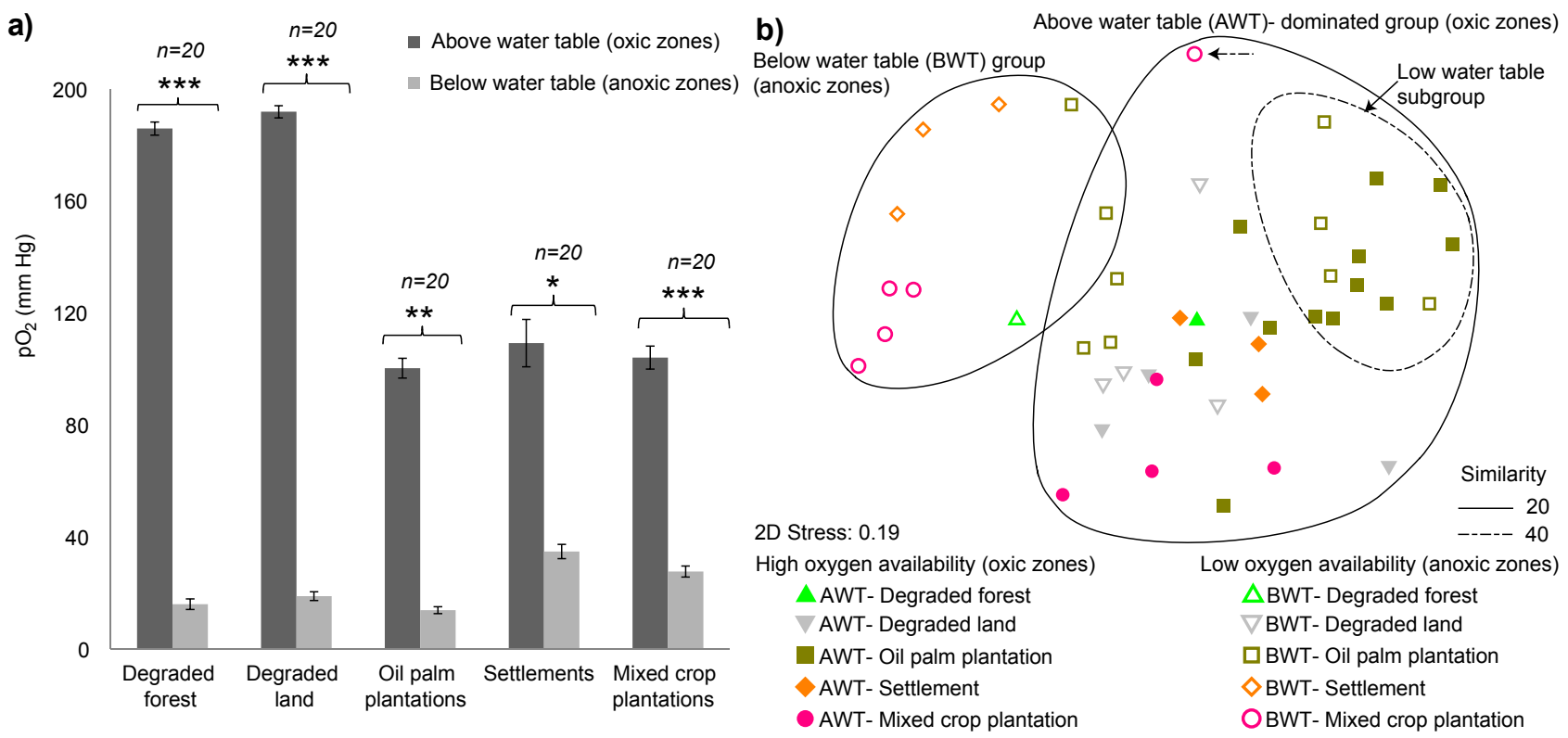

Fig. 2. Oxygen levels $\left(p \mathrm{O}_{2}\right), \mathrm{mm} \mathrm{Hg}(\mathbf{a})$ and nonmetric multidimensional scaling (nMDS) ordination plot based on Bray-Curtis similarities calculated from presence/absence data of $16 \mathrm{~S}$ rDNA TRFs abundances (b) at above (oxic zones) and below (anoxic zones) water table positions in different land-use types. Level of significance in (a) is ${ }^{*} p<0.05$, ${ }^{* *} p<0.01$, and ${ }^{* * *} p<0.001$, and $n=$ total number of independent measurements.

Table 1. Shannon diversity indices for different land-use patterns based on $16 \mathrm{~S}$ rDNA and metabolic diversity.

\begin{tabular}{|c|c|c|c|}
\hline $\begin{array}{l}\text { Land-use } \\
\text { patterns }\end{array}$ & $\begin{array}{c}\text { Above } \\
\text { water } \\
\text { table } \\
\text { (oxic } \\
\text { zones) }\end{array}$ & $\begin{array}{c}\text { Below } \\
\text { water } \\
\text { table } \\
\text { (anoxic } \\
\text { zones) }\end{array}$ & $\begin{array}{c}\text { Metabolic } \\
\text { diversity }\end{array}$ \\
\hline Degraded forest & 3.14 & 3.53 & 4.07 \\
\hline Degraded land & 3.44 & 3.27 & 4.28 \\
\hline Settlements & 3.19 & 3.38 & 4.24 \\
\hline Oil palm plantations & 2.62 & 2.68 & 4.33 \\
\hline Mixed crop plantations & 3.48 & 3.62 & 4.47 \\
\hline
\end{tabular}

Average diversity indices for different land-use patterns based on $16 \mathrm{~S}$ rDNA were within \pm 0.17 and \pm 0.08 in the oxic and anoxic zones, respectively.

Between-site comparisons of bacterial community composition showed statistically significant clustering based on water table level in oxic zones (Fig. 3b; Table 2: one-way ANOSIM values)

Water table depth greatly influenced bacterial diversity in both oxic and anoxic zones, with the influence being greater in the oxic zone. In order to determine the relative influences of different peat characteristics, we analyzed pair-wise combinations of peat characteristics using two-way ANOSIM analysis. It revealed major influence of water table and land-use pattern over other characteristics, namely, age of drainage and peat thickness (Table 2: two-way ANOSIM values). The variations in bacterial communities due to water table differences for both oxic and anoxic zones were significant across land use, peat thickness and age of drainage (Table 2: two-way ANOSIM values).

\subsubsection{Land-use pattern, age of drainage and peat thickness}

Unlike the oxic zone, where water table was the predominant factor influencing bacterial community structure, in the anoxic zone, land-use pattern had equally as strong an influence as water table on bacterial community structure (Table 2). In such anoxic zones, the bacterial diversity decreased in different land-use types in the following order: mixed crop plantations $>$ degraded forest $>$ settlements $>$ degraded land $>$ oil palm plantations (Table 1). In both oxic and anoxic zones, highest diversity of bacterial communities was found in mixed crop plantations, whereas least diversity was present in oil palm plantations.

Age of drainage and peat thickness had a weaker yet statistically significant effect as compared to water table and land-use patterns in shaping the bacterial community profiles in both oxic and anoxic zones (Table 2: One-way ANOSIM values). In the ordination plot of the bacterial communities based on age of drainage, two sub-groups dominated by lowwater-table sites and mixed crop plantations, respectively, revealed that these two parameters had additional influences (Supplement Fig. S1). Similar to age of drainage, in the ordination plot based on peat thickness, there was a sub-group of low-water-table sites in oxic zones (Fig. 3b). 
Table 2. One-way (bold letters in diagonal cells) and Two-way (non-bold letters in off-diagonal cells) ANOSIM showing variation in bacterial community structure due to an individual parameter across other parameters tested in oxic and anoxic zones. The top value in each white cell refers to influence by the individual parameter across others (left to right), whereas the bottom value in the same white cell shows the converse (right to left). Values in white cells can be directly compared within same white cells or between white cells of oxic and anoxic zones. As an example of within-white cell comparison: in oxic zones, the influence of water table was much higher across different land-use patterns (global R: 0.702), peat depth (0.946) and age of drainage (0.609) than vice versa $(0.189,0.344$, NS: -0.009$)$, respectively. However, in anoxic zones, land-use pattern had high influence across water table (0.468), peat depth (0.636) and age of drainage (0.532), respectively.

\begin{tabular}{|c|c|c|c|c|c|c|c|c|c|}
\hline \multicolumn{10}{|c|}{ Global R statistics } \\
\hline \multicolumn{5}{|c|}{ Above-water-table (oxic) zones } & \multicolumn{5}{|c|}{ Below-water-table (anoxic) zones } \\
\hline & $\begin{array}{l}\text { Water } \\
\text { table }\end{array}$ & $\begin{array}{l}\text { Land } \\
\text { use }\end{array}$ & $\begin{array}{l}\text { Peat } \\
\text { depth }\end{array}$ & $\begin{array}{l}\text { Age of } \\
\text { drainage }\end{array}$ & & $\begin{array}{l}\text { Water } \\
\text { table }\end{array}$ & $\begin{array}{l}\text { Land } \\
\text { use }\end{array}$ & $\begin{array}{l}\text { Peat } \\
\text { depth }\end{array}$ & $\begin{array}{l}\text { Age of } \\
\text { drainage }\end{array}$ \\
\hline Water table & $0.527^{c}$ & $\begin{array}{l}0.702^{\mathrm{b}} \\
0.189^{\mathrm{a}}\end{array}$ & $\begin{array}{l}0.946^{\mathrm{b}} \\
0.344^{\mathrm{a}}\end{array}$ & $\begin{array}{l}0.609^{c} \\
-0.009\end{array}$ & Water table & $0.359^{b}$ & $\begin{array}{l}0.541^{\mathrm{a}} \\
0.468^{\mathrm{b}}\end{array}$ & $\begin{array}{l}0.878^{\mathrm{a}} \\
0.266^{\mathrm{a}}\end{array}$ & $\begin{array}{l}0.66^{\mathrm{b}} \\
0.247^{\mathrm{a}}\end{array}$ \\
\hline Land use & & $0.267^{\mathrm{a}}$ & $\begin{array}{l}0.485^{\mathrm{b}} \\
0.358\end{array}$ & $\begin{array}{l}0.361^{b} \\
0.76^{b}\end{array}$ & Land use & & $0.413^{b}$ & $\begin{array}{l}0.636^{\mathrm{c}} \\
0.268\end{array}$ & $\begin{array}{l}0.532^{\mathrm{c}} \\
0.101\end{array}$ \\
\hline Peat depth & & & $0.214^{b}$ & $\begin{array}{l}0.433^{\mathrm{c}} \\
0.574^{\mathrm{b}}\end{array}$ & Peat depth & & & $0.165^{\mathrm{a}}$ & $\begin{array}{l}0.563^{b} \\
0.643^{b}\end{array}$ \\
\hline Age of drainage & & & & $0.389^{c}$ & Age of drainage & & & & $0.192^{\mathrm{a}}$ \\
\hline
\end{tabular}

Level of significance is ${ }^{\mathrm{a}} p<0.05,{ }^{\mathrm{b}} p<0.01,{ }^{\mathrm{c}} p \leq 0.001$.

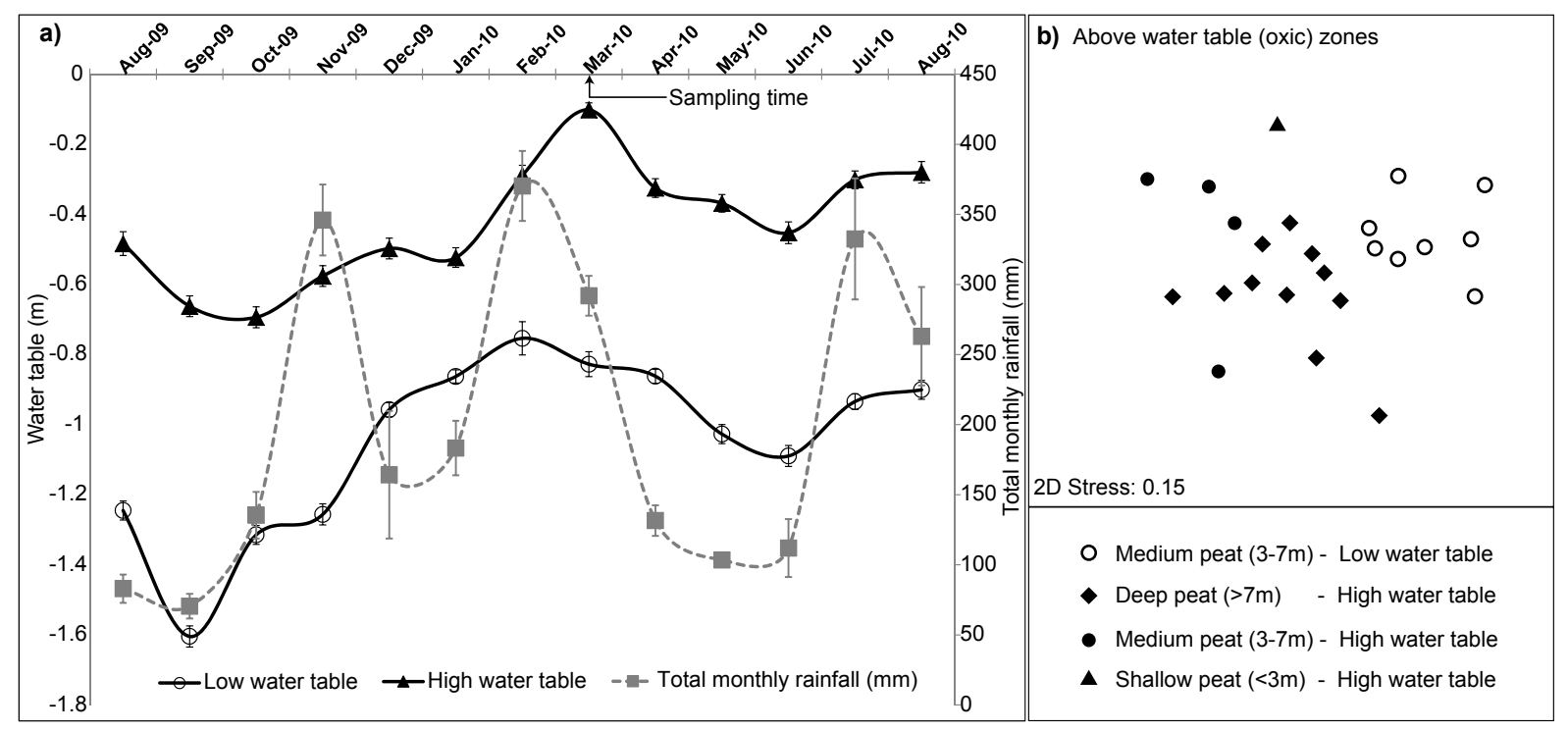

Fig. 3. (a) Rainfall and water table data from August 2009 to August 2010 at all sampling locations from Site A and Site B. The locations are shown in Fig. 1. Water table levels were averaged across locations within high water table $(0-45 \mathrm{~cm})$ and low water table $(>45 \mathrm{~cm})$, respectively. The averaged values are represented as "high water table" and "low water table", respectively. (b) Nonmetric multidimensional scaling (nMDS) ordination plot, based on Bray-Curtis similarities calculated from presence/absence data of 16 S rDNA TRFs abundances, showing variation between bacterial community across different water table depth and peat thickness, from above (oxic zones) water table positions. Low-water-table (LWT), high-water-table (HWT) and different peat thickness samples are represented by open symbols, closed symbols and different shapes, respectively.

\subsection{Distribution of bacterial taxa}

In order to identify the dominant members of the bacterial communities, we predicted the taxa using the TRFs. To vali- date the taxa group identified, a clone library was created that revealed differences in abundance of taxa based on water table, land-use pattern and oxygen availability (Table 3), which was consistent with our previous findings (Figs. 2 and 3b). 
Table 3. Correspondence of clone data in comparison to predicted species. "AWT": above-water-table samples; "BWT": below-water-table samples.

\begin{tabular}{|c|c|c|c|c|c|c|c|c|c|}
\hline \multirow[b]{2}{*}{$\begin{array}{l}\text { Species } \\
\text { distribution } \\
\text { (taxonomic level) }\end{array}$} & \multicolumn{3}{|c|}{$\begin{array}{c}\text { MLPO-AWT ( from oxic zones) } \\
\text { (Medium peat-low water table-oil } \\
\text { palm plantations-drainage }>10 \text { years) }\end{array}$} & \multicolumn{3}{|c|}{$\begin{array}{l}\text { DHTO-AWT (from oxic zones) } \\
\text { (Deep peat-high water table- } \\
\text { settlements-drainage }>10 \text { years) }\end{array}$} & \multicolumn{3}{|c|}{$\begin{array}{l}\text { DHTO-BWT (from anoxic zones) } \\
\text { (Deep peat-high water table- } \\
\text { settlements-drainage }>10 \text { years) }\end{array}$} \\
\hline & $\begin{array}{l}\text { No. of } \\
\text { clones } \\
(102)\end{array}$ & $\begin{array}{l}\text { No. of } \\
\text { predicted } \\
\text { taxa by } \\
\text { FRAGSORT }\end{array}$ & $\begin{array}{c}\% \\
\text { coverage }\end{array}$ & $\begin{array}{l}\text { No. of } \\
\text { clones } \\
(104)\end{array}$ & $\begin{array}{l}\text { No. of } \\
\text { predicted } \\
\text { taxa by } \\
\text { FRAGSORT }\end{array}$ & $\begin{array}{c}\% \\
\text { coverage }\end{array}$ & $\begin{array}{l}\text { No. of } \\
\text { clones } \\
(96)\end{array}$ & $\begin{array}{c}\text { No. of } \\
\text { predicted } \\
\text { taxa by } \\
\text { FRAGSORT }\end{array}$ & $\begin{array}{c}\% \\
\text { coverage }\end{array}$ \\
\hline Gammaproteobacteria & 19 & 34 & 56.7 & 25 & 28 & 89.3 & 15 & 23 & 65.2 \\
\hline Alphaproteobacteria & 5 & 45 & 11.2 & 10 & 41 & 24.4 & 3 & 41 & 7.3 \\
\hline Acidobacteria & 5 & 5 & 100.0 & 73 & 3 & 100.0 & 2 & 2 & 100.0 \\
\hline Actinobacteria & 0 & 53 & 0.0 & 1 & 49 & 2.0 & 0 & 22 & 0.0 \\
\hline Betaproteobacteria & 2 & 44 & 4.5 & 2 & 37 & 5.4 & 2 & 41 & 4.9 \\
\hline Planctomycetes & 0 & 12 & 0.0 & 1 & 9 & 11.1 & 0 & 14 & 0.0 \\
\hline
\end{tabular}

Acidobacteria had $100 \%$ similarity with the predicted taxa as mentioned above for all the sites sampled for clone library. The coverage between the predicted taxa and clones identified for Gammaproteobacteria ranged from 56.7 to $89.3 \%$ between the sites sampled. The highest coverage between the predicted taxa and clones identified was found in the site with settlements in oxic zones. Based on sequence database searches with the clone sequences, two species were identified based on identities to known entries. Out of which, Brevundimonas sp., reported initially from saline soils (Wang et al., 2012), was found abundant in settlements.

Oxygen availability had a strong influence on the abundance of bacterial taxa in high and low water table depths (Supplement Fig. S2). In the oxic zones, the water table did not affect taxa abundance, whereas, in the anoxic zones, all major taxa were more abundant in the low-water-table sites. Among the five most abundant taxa $(\alpha-, \beta$ - and $\gamma-$ Proteobacteria, Actinobacteria and Firmicutes Bacillales), Actinobacteria had the largest difference in abundance between high and low water table sites in both oxic and anoxic zones.

\subsection{Relationship of environmental and geochemical parameters with bacterial community structure}

Canonical correspondence analysis was used to identify the association of environmental and geochemical traits with bacterial communities from different land-use patterns (Fig. 4a, b and Supplement Table S1). Bacterial communities from the oil palm plantations were associated with nitrate levels in both oxic (Fig. 4a) and anoxic (Fig. 4b) zones. Nitrate levels were lower in the anoxic zones compared to oxic zones by a factor of 20-30, which is likely to drive differences in their community structures. Bacterial communities in the mixed crop plantations, on the other hand, were mainly associated with DOC, ammonium and phosphates. Salinity had some influence on bacterial communities from sites with mixed crop plantations and settlements; the latter corroborated the identified salinity-associated species from settlements.

Metabolic profiling of peat water from different land-use patterns was performed (Fig. 5) and was compared with bacterial profiling (Fig. 2b) to directly evaluate the effects of bioavailable organics that influence the bacterial communities. Bacterial communities from anoxic zones were marginally separated based on land-use patterns (Fig. 2b). The communities were separated based on habitat, as revealed by significant separation of the flooded site (indicated by arrow) from the non-flooded sites of mixed crop plantations (Fig. 2b). When comparing the functional data from metabolic profiling (Fig. 5), distinct clusters of different land-use types were formed. Metabolic profiling not only differentiates the land-use patterns but also clearly distinguishes samples based on geographical sampling position. For example, two sites from degraded land in Site B formed a distinct cluster from the other two sites from degraded land in Site A (DHAN in Fig. 1). Similarly, two oil palm plantation samples (extreme left of Fig. 5), though belonging to different peat thickness (MHPN and DHPN in Fig. 1), were clustered very close as they were from the same transect.

\section{Discussion}

Bacterial and metabolic markers that represent the complex nature of bacterial communities and metabolic processes of diverse biota, respectively, provided the resolving power to distinguish different habitats. This resolution ranged from centimeter scale in depth measurements to kilometer scale, where sites were distributed within the $48 \mathrm{~km}^{2}$ of the study 

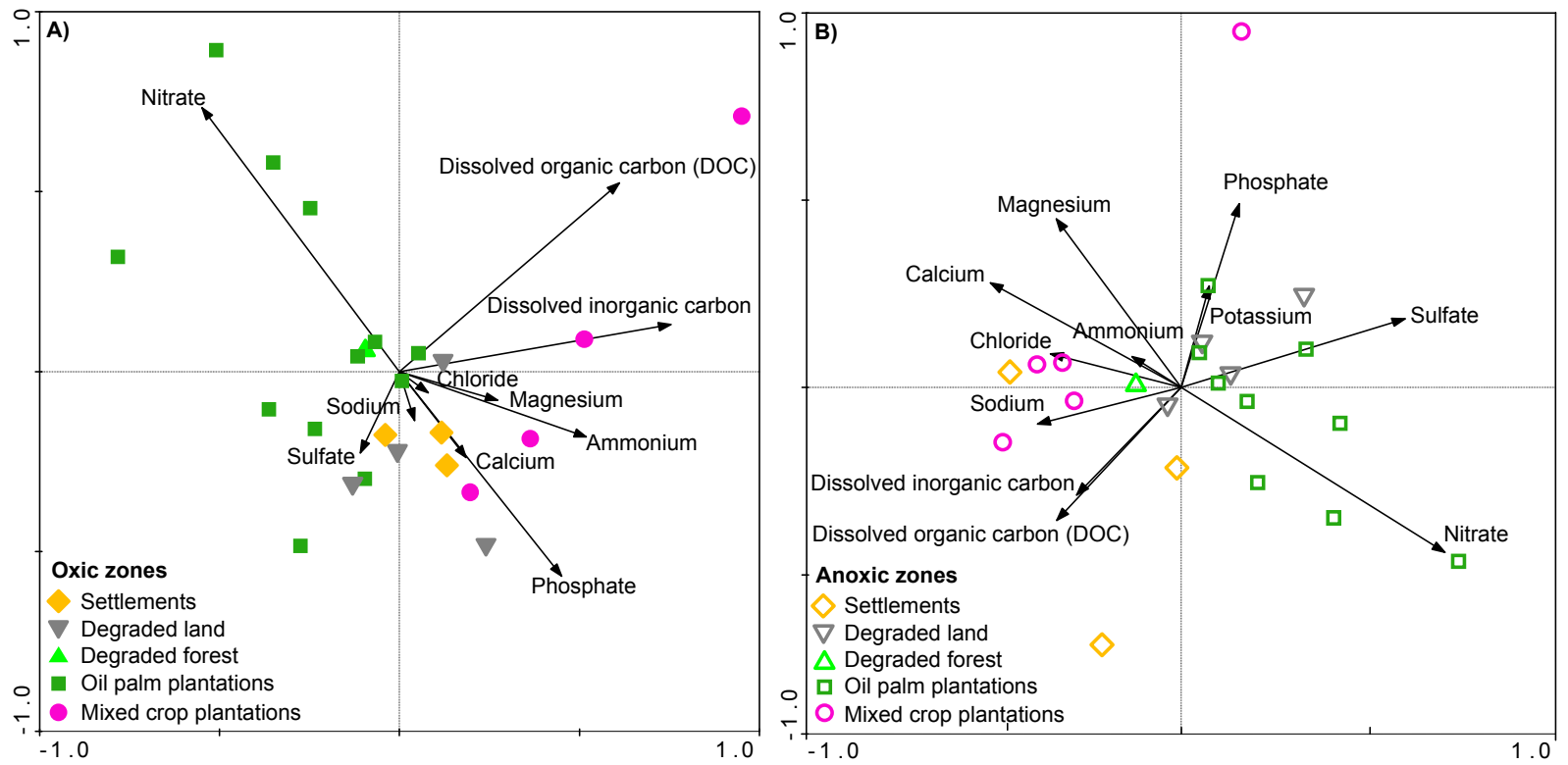

Fig. 4. Canonical correspondence analysis of $16 \mathrm{~S}$ rDNA gene based T-RFLP data sets and environmental data in different land-use patterns from oxic (a) and anoxic (b) zones. Geochemical data, represented with arrows, are nitrates, dissolved organic carbon (DOC), dissolved inorganic carbon, chloride, magnesium, ammonium, sodium, calcium, sulfate and phosphate. Test of significance ( $p$ value) of all canonical axes is 0.05 and 0.009 in oxic (a) and anoxic (b) zones, respectively.

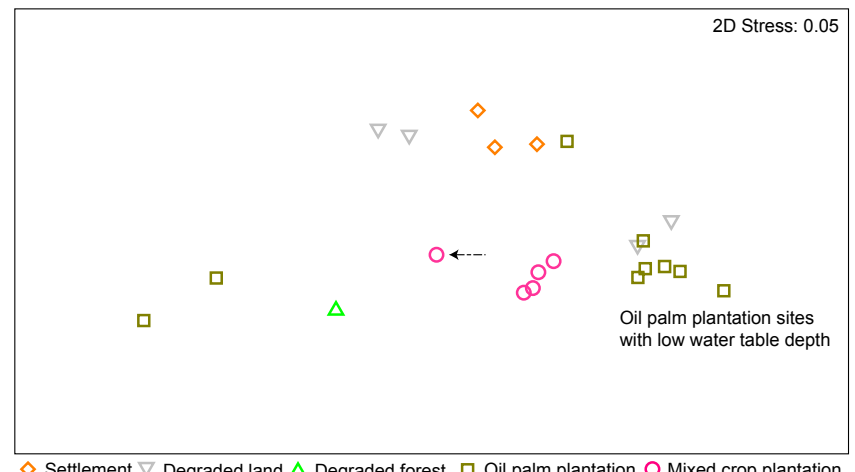

Fig. 5. Nonmetric multidimensional scaling (nMDS) ordination plot, based on Euclidean distance calculated from intensity of metabolites extracted from peat water of different land-use patterns. The arrow represents the flooded site with mixed crop plantations.

area. Thus, the same set of molecular markers provided a dynamic range of resolution at four orders of magnitude. Microbial markers have been extensively used to study alteration in community structures due to changes in land-use patterns at large scales of spatial distribution, such as in $\mathrm{Pa}-$ cific Northwest marine sediment communities (Braker et al., 2000), in high levels of nuclear-waste-contaminated vadose sediments at the Hanford Site in the US (Fredrickson et al., 2004), in western Amazon soils (Jesus et al., 2009) and in Antarctic dry valley (Chan et al., 2013), among other biogeographic locations. In comparison, there are relatively few studies that have used metabolites as function-based markers for understanding variation at large scales of spatial distribution. Both sets of molecular markers distinguished different land-use types, but with different levels of resolution. Compared with microbial profiles, those of metabolites were additionally able to differentiate land-use types from locations that are separated by nearly $8 \mathrm{~km}$ distance. Our findings about bacterial profiling have led us to identify geochemical factors that influence the state of degraded peatlands. In addition, metabolic profiling, which relies on markers derived from functions of diverse biotic communities and not just bacteria, provide a finer classification of peatland sites. Metabolic profiling can, therefore, be used in developing better practices for mapping peatlands, which can be a tool for both management and policy development.

While there have been reports of effects of land-use change and hydrology on $\mathrm{CO}_{2}, \mathrm{~N}_{2} \mathrm{O}$ and $\mathrm{CH}_{4}$ emissions (Jauhiainen et al., 2008, 2012a, b) and hydrology on subsidence (Hooijer et. al., 2010, 2012), our approach allows multiple parameters to be evaluated simultaneously using a single molecular profiling approach. Our findings show that microbial profiles from peatland sites are most influenced by variations in water table and land-use patterns. These two are followed by age of drainage and peat thickness in influencing the bacterial community structure. Across degraded peatland that are under hydrological management, water table fluctuates due to drainage, rainfall and other physical parameters (Jauhiainen et al., 2008; Hooijer et al., 2010). The ability of microbial markers to distinguish the low- and high-watertable sites shows their robustness to capture differences in community structures despite the differences in the range of 
fluctuations in water level at these sites. Fluctuations in water table are likely to influence bacterial community structure through oxygen and nutrient availability on the one hand and selection of bacteria that can withstand drying-wetting cycles on the other hand. Such changes in microbial community structure along a hydrological gradient have been reported in other natural ecosystems, such as in forested, temperate pine wetlands (Yu and Ehrenfeld, 2010). However, temporal fluctuations in water table in high- and low-water-table sites leading to rapid drying and wetting, as seen here, were not present in the pine wetland study. Hence, microbial profiling presents a practical approach to monitor peat responses to both rapid short-term and long-term hydrological changes.

Mechanisms by which water table influences microbial communities are likely to be different in a depth profile, depending on oxygen availability. In the oxic zones, lowwater-table sites undergo more pronounced cycles of drying and wetting compared to high-water-table sites. Drying and wetting of peat leads to alternating aerobic and anaerobic physiological responses of the microbes. Thus, dryingwetting process selectively enriches those resilient members of microbial communities that can tolerate these changes both in physical environment and physiological functions. Examples of such successful resilient bacterial taxa are Actinobacteria and Firmicutes that have a very thick peptidoglycan layer to withstand changes in the physical environment and adapt to a broad range of oxygen availability. Hence, they thrive well in diverse and extreme environments from deep sea to dry deserts (Cowan and Tow, 2004; Bull, 2011). Actinobacteria and Firmicutes were the most represented taxa groups in all our study sites, irrespective of water table depth, land-use pattern or oxygen availability. Physiologically, aerobic-anaerobic cycling can affect both nitrogen and carbon metabolism. Denitrifying assemblages are favored under the wetter and low-oxygen conditions of the dryingwetting cycles, as shown in clay loam of wetland mesocosms (Peralta et al., 2013). Likewise, in carbon metabolism, this cycling is known to activate different pathways in oxic and anoxic conditions. Enzyme systems, such as phenol oxidase and $\beta$-glucosidase that are involved in the degradation of recalcitrant phenolic (lignin and its derivative) and cellulosic materials, respectively, are active in high-oxygen conditions (McLatchey and Reddy, 1998). On the other hand, activities of many hydrolases that degrade complex carbon polymers are high under low-oxygen conditions, such as in boreal river systems (Sinsabaugh et al., 1992), in anaerobic sludge digester (Nybroe et al., 1992) and in the rumen of cattle (Lee et al., 1999). Such activation of different groups of enzymes in drying-wetting has been reported from mesocosms of peat in the boreal region (Fenner and Freeman, 2011). Combined oxidation of recalcitrant and labile carbon, accompanied with outgassing of carbon dioxide can lead to direct loss of peat. This extrapolation directly predicts that peat loss will be higher in low-water sites, where these pronounced cycles of drying-wetting are prevalent, compared to high-water-table sites. From sites in the Sumatran region, peat subsidence that is considered a proxy for carbon loss is indeed higher in low-water sites (water table depth: $-0.7 \pm 0.2 \mathrm{~m}$; subsidence rate: $5 \pm 2.2 \mathrm{~cm} \mathrm{yr}^{-1}$ ), when compared to high-watertable sites (water table depth: $-0.56 \pm 0.06 \mathrm{~m}$; subsidence rate: $3.9 \pm 0.5 \mathrm{~cm} \mathrm{yr}^{-1}$ ) (Couwenberg and Hooijer, 2013).

In contrast to the oxic zones in low-water-table sites that experience fluctuations, the anoxic conditions present in the water-saturated zones of low- and high-water-table sites affect microbial communities through possibly different mechanisms. The first is through exposure of microbial communities to prolonged stable anoxic conditions. Such conditions can support both high bacterial diversity and abundance, as shown in this study. Consistent with our findings, similar increase in bacterial diversity with decreasing oxygen availability along a depth profile has been reported in a stratified lake (Garcia et al., 2013). The second mechanism is through direct effects of water saturation in the anoxic zones, where dissolved organic matter becomes freely available for microbial communities. Availability of dissolved organic matter in the water-saturated anoxic zone plays a major role in shaping microbial communities, through its quantity and composition. Both root exudation from plant communities and degradation products of lignocellulosic materials contribute to the dissolved organic matter that drives microbial assemblages (Farrar et al., 2003). Hence, dissolved organic matter provides a critical link between the above- and below-ground communities (Wardle et al., 2004). Microbial and metabolic profiling approaches in our study, therefore, capture the outcomes of these plant-microbial-peat interactions. Such interactions are heavily impacted by changes in land-use patterns, where different plant communities support their land-coverspecific microbial populations (Bardgett et al., 2005).

The nutrient pool for microbes is influenced not only by root exudates and lignocellulosic degradation products, but also by the carbon products resulting from fire events. Both aliphatic and aromatic carbons are added to the pool of dissolved organic matter present in the ecosystems that have experienced fire events, as shown for pine forest (Czimczik et al. 2003) and boreal ecosystems (Neff et al., 2005). All our sites, with the exception of degraded forest, also have fire histories of 5-10 years, which likely contributed fire-related carbon forms to the nutrient pools. While such carbon joins the carbon pool after fire events, as expected, there is a concomitant decrease in abundance and activity of microbial communities immediately after the fire events in forest soils (Certini, 2005). The present state of microbial assemblages at our sites, therefore, reflects the recovered and adapted communities over a period of time. Southeast Asian peatlands have a unique history of experiencing repeated fires, which both can be spatially extensive and can affect specific sites at multiple occasions. Our findings that the bacterial communities and metabolic profiles could not separate the sites based on fire history indicates resilience of the microbial communities to recover over a 5-10-year period, since the sites first 
experienced a fire event. This duration of recovery is consistent with that reported for boreal forest fires (Dooley and Treseder, 2012). Whether functionally important, yet nonresilient bacteria are lost in this process cannot be ascertained from our current approach and will require metagenomics approaches.

Anthropogenic chemical inputs, such as by fertilization, in these managed peatlands had a great influence on bacterial community structure. Nitrates and phosphates, contributed by application of fertilizers, were among the top three factors that influenced overall bacterial diversity in oil palm plantations. A similar influence of organic manure and mineral fertilizer treatment occurs on the abundance and diversity of gram-negative bacteria, Actinobacteria and fungal communities in the red soil of China (Zhong et al., 2010). Since nitrogenous fertilizers are heavily used in the management of plantations on tropical peatlands, $\mathrm{N}_{2} \mathrm{O}$ is likely to be released, as demonstrated from other agricultural lands, such as from agricultural soils in Australia (Dalal et al., 2003), India (Aggarwal, 2008) and Africa (Hickman et al., 2011). One of the most abundant taxa in our study, Actinobacteria have been shown to actively reduce $\mathrm{N}_{2} \mathrm{O}$ to $\mathrm{N}_{2}$ not only in the anoxic zone of palsa peat (Palmer and Horn, 2012) but also in other habitats, such as agricultural soils (Philippot et al., 2002) and in uranium-contaminated sediments (Akob et al., 2008). Hence, it will be important to estimate $\mathrm{N}_{2} \mathrm{O}$ emissions from tropical peat plantations that use mineral fertilizers and also the utility of $\mathrm{N}_{2} \mathrm{O}$-reducing bacteria in such plantations. In contrast to plantations, salinity is a major influencing factor in settlements and mixed crop plantations. Both these land-cover types have most intensive human activities. Salinity is likely to be due to anthropogenic contributions. Nearly $2.5 \mathrm{~km}^{2}$ out of the total study area of $48 \mathrm{~km}^{2}$ belongs to settlements and mixed crop plantations, thus representing a significant influence on the microbial communities in this region. Hence, microbial profiling can help reveal influences of both management-related and anthropogenic activities on peat.

One of the major findings of our study is that monoculture of oil palm plantations supported the least diverse bacterial communities and consisted of lowest levels of dissolved carbon content. On the other hand, mixed crop plantations consisting of up to five plant species only, supported most diverse bacterial communities and had the highest levels of dissolved carbon content. In tropical peatlands of Kalimantan, land conversion from secondary forest to paddy field (monoculture plantations) led to a decrease in carbon content, together with a decrease in microbial abundance (Hadi et al., 2001), which is consistent with our findings. Carbon levels increased when paddy-soybean rotation cropping was followed with a further decrease in microbial abundance. This possibly underlines the importance of adopting simultaneously mixed plantations rather than sequential crop rotations, as evident in our study. A similar decrease in microbial diversity from mixed crop plantations to monoculture of crops has been reported for many cases such as Lolium, Trifolium spp., Plathymenia, Sudan grass and tall fescue (Marilley et al., 1998; Meimei et al., 2008; Pagano et al., 2009; Zarea et al., 2009). Similarly, microbial diversity is lower in fallow and woodland, when compared to grassland with multiple plant communities on temperate peatlands (Brake et al., 1999). Low bacterial diversity in oil palm plantations, as seen in our study, can be sensitive to environmental pressures, thereby leading to a reduction in productive period of plantations. These findings provide a good basis to adopt microbial ecology principles to encourage mixed crop planting in the existing plantations, in order to increase their microbial diversity, especially of beneficial microbes, which can lead to sustainable use of these plantations.

\section{Supplementary material related to this article is available online at http://www.biogeosciences.net/11/ 1727/2014/bg-11-1727-2014-supplement.pdf.}

Acknowledgements. We thank NUS Environmental Research Institute (NERI), Department of Biological Sciences, NUS, and Singapore-Delft Water Alliance (SDWA) for their funding and infrastructure support. We thank Choon Nam Ong for his insightful comments and kind support throughout the program. We also thank Ryan Chisholm for his suggestions during critical reading of the manuscript. Thanks also to Lee Li Kheng and Kalyan Mynampati for their support on GIS and metabolic profiling software, respectively. Lastly, we thank Sugino, research staff from University of Jambi, for his assistance during the field work. The research presented in this work was supported by funding from the National Research Foundation and the Economic Development Board (SPORE, COY-15-EWI-RCFSA/N197-1), NERI (WBS: R-706-000-008-646) and SDWA (R264-001-011-490).

Edited by: T. J. Battin

\section{References}

Aggarwal, P. K.: Global climate change and Indian agriculture: impacts, adaptation and mitigation, Indian J. Agr. Sci., 78, 911-919, 2008.

Akob, D. M., Mills, H. J., Gihring, T. M., Kerkhof, L., Stucki, J. W., Anastacio, A. S., Chin, K., Kusel, K., Palumbo, A. V., Watson, D. B., and Kostka, J. E. : Functional diversity and electron donor dependence of microbial populations capable of $U(V I)$ reduction in radionuclide contaminated subsurface sediments, Appl. Environ. Microb., 74, 3159-3170, 2008.

Anderson, J. A. R.: The structure and development of peat swamps of Sarawak and Brunei, J. Trop. Geogr., 18, 7-16, 1964.

Ashelford, K. E., Chuzhanova, N. A., Fry, J. C., Jones, A. J., and Weightman, A. J.: New screening software shows that most recent large 16S rRNA gene clone libraries contain chimeras, Appl. Environ. Microbiol., 72, 5734-5741, 2006. 
Ausec, L., Kraigher, B., and Mandic-Mulec, I.: Differences in the activity and bacterial community structure of drained grassland and forest peat soils, Soil Biol. Biochem., 41, 1874-1881, 2009.

Bai, S., Li, J., He, Z., Nostrand, J. D. V., Tian, Y., Lin, G., Zhou, J., and Zheng, T.: GeoChip-based analysis of the functional gene diversity and metabolic potential of soil microbial communities of mangroves, Appl. Microbiol. Biot., 97, 7035-7048, 2013.

Bardgett, R. D., Bowman, W. D., Kaufmann, R., and Schmidt, S. K.: A temporal approach to linking aboveground and belowground ecology, Trends Ecol. Evol., 20, 634-641, 2005.

Brake, M., Hoper, H., and Joergensen, R. G.: Land use-induced changes in activity and biomass of microorganisms in raised bog peats at different depths, Soil Biol. Biochem., 31, 1489-1497, 1999.

Braker, G., Zhou, J., Wu L., Devol, A. H., and Tiedje, J. M.: Nitrite reductase genes (nirK and nirS) as functional markers to investigate diversity of denitrifying bacteria in Pacific Northwest marine sediment communities, Appl. Environ. Microb., 66, 20962104, 2000 .

Bull, A. T.: Actinobacteria of the Extremobiosphere, Extremophiles Handbook, 1203-1240, 2011.

Bundy, J. G., Davey, M. P., and Viant, M. R.: Environmental metabolomics: a critical review and future perspectives, Metabolomics, 5, 3-21, 2009.

Certini, G.: Effects of fire on properties of forest soils: a review, Oecologia, 143, 1-10, 2005.

Chan, Y., Nostrand, J. D. V., Zhou, J., Pointing, S. B., and Farrell, R. L.: Functional ecology of an Antarctic Dry Valley, P. Natl. Acad. Sci. USA, 110, 8990-8995, 2013.

Chistoserdova, L.: Recent progress and new challenges in metagenomics for biotechnology, Biotechnol. Lett., 32, 1351-1359, 2010.

Clarke, K. R.: Non-parametric multivariate analyses of changes in community structure, Aust. J. Ecol., 18, 117-143, 1993.

Couwenberg, J. and Hooijer, A.: Towards robust subsidence-based soil carbon emission factors for peat soils in south-east Asia, with special reference to oil palm plantations, Mires and Peat, 12, 113, 2013.

Couwenberg, J., Dommain, R., and Joosten, H.: Greenhouse gas fluxes from tropical peatlands in south-east Asia, Glob. Change Biol., 16, 1715-1732, 2010.

Cowan, D. A. and Tow, L. A.: Endangered Antarctic environments, Annu. Rev. Microbiol., 58, 649-690, 2004.

Czimczik, C. I., Preston, C. M., Schmidt, M. W. I., and Schulze, E. D.: How surface fire in Siberian Scots pine forests affects soil organic carbon in the forest floor: stocks, molecular structure, and conversion to black carbon (charcoal), Global Biogeochem. Cy., 17, 1020-1034, 2003.

Dalal, R. C., Wang, W., Robertson, P., and Parton, W. J.: Nitrous oxide emission from Australian agricultural lands and mitigation options: a review, Aust. J. Soil Res., 41, 165-195, 2003.

Dooley, S. R. and Treseder, K. K.: The effect of fire on microbial biomass: a meta-analysis of field studies, Biogeochemistry, 109, 49-61, 2012.

Farrar, J., Hawes, M., Jones, D., and Lindow, S.: How roots control the flux of carbon to the rhizosphere, Ecology, 84, 827-837, 2003

Fenner, N. and Freeman, C.: Drought-induced carbon loss in peatlands, Nat. Geosci., 4, 895-900, 2011.
Fierer, N., Schimel, J., and Holden, P.: Variations in microbial community composition through two soil depth pro?les, Soil Biol. Biochem., 35, 167-176, 2003.

Finlayson, C. M., Davidson, N. C., Spiers, A. G., and Stevenson, N. J.: Global wetland inventory- current status and future priorities, Mar. Freshwater Res., 50, 717-727, 1999.

Fredrickson, J. K., Zachara, J. M., Balkwill, D. L., Kennedy, D., Li, S. W., Kostandarithes, H. M., Daly, M. J., Romine, M. F., and Brockman, F. J.: Geomicrobiology of High-Level Nuclear Waste-Contaminated Vadose Sediments at the Hanford Site, Washington State, Appl. Environ. Microb., 70, 4230-4241, 2004.

Freeman, C., Fenner, N., and Shirsat, A. H.: Peatland geoengineering: an alternative approach to terrestrial carbon sequestration, Philos. T. R. Soc. A, 370, 4404-4421, 2012.

Furukawa, Y., Inubushi, K., Ali, M., Itang, A. M., and Tsuruta, H.: Effect of changing groundwater levels caused by land-use changes on greenhouse gas fluxes from tropical peatlands, Nutr. Cycl. Agroecosys., 71, 81-91, 2005.

Garcia, S. L., Salka, I., Grossart, H., and Warnecke, F.: Depthdiscrete profiles of bacterial communities reveal pronounced spatio-temporal dynamics related to lake stratification, Environ. Microbiol. Reports, 5, 549-555, 2013.

Hadi, A., Haridi, M., Inubushi, K., Purnomo, E., Razie, F., and Tsuruta, H.: Effects of land-use change in tropical peat soil on the microbial population and emission of greenhouse gases, Microbes Environ., 16, 79-86, 2001.

He, Z., Xu, M., Deng, Y., Kang, S., Kellogg, L., Wu, L., Nostrand, J. D. V., Hobbie, S. E., Reich, P. B., and Zhou, J.: Metagenomic analysis reveals a marked divergence in the structure of belowground microbial communities at elevated $\mathrm{CO}_{2}$, Ecol. Lett., 13, 564-575, 2010.

He, Z., Piceno, Y., Deng, Y., Xu, M., Lu, Z., DeSantis, T., Andersen, G., Hobbie, S. E., Reich, P. B., and Zhou, J.: The phylogenetic composition and structure of soil microbial communities shifts in response to elevated carbon dioxide, ISME J., 6, 259-272, 2012.

Hergoualc'h, K. and Verchot, L. V.: Stocks and fluxes of carbon associated with land use change in Southeast Asian tropical peatlands: a review, Global Biogeochem. Cy., 25, GB2001, doi:10.1029/2009GB003718, 2011.

Hickman, J. E., Havlikova, M., Kroeze, C., and Palm, C. A.: Current and future nitrous oxide emissions from African agriculture, Curr. Opin. Environ. Sustain., 3, 370-378, 2011.

Hooijer, A., Page, S., Canadell, J. G., Silvius, M., Kwadijk, J., Wösten, H., and Jauhiainen, J.: Current and future $\mathrm{CO}_{2}$ emissions from drained peatlands in Southeast Asia, Biogeosciences, 7, 1505-1514, doi:10.5194/bg-7-1505-2010, 2010.

Hooijer, A., Page, S., Jauhiainen, J., Lee, W. A., Lu, X. X., Idris, A., and Anshari, G.: Subsidence and carbon loss in drained tropical peatlands, Biogeosciences, 9, 1053-1071, doi:10.5194/bg-91053-2012, 2012.

Jackson, C. R., Liew, K. C., and Yule, C. M.: Structural and Functional Changes with Depth in Microbial Communities in a Tropical Malaysian Peat Swamp Forest, Microb. Ecol., 57, 402-412, 2009.

Jauhiainen, J., Limin, S., Silvennoinen, H., and Vasander, H.: Carbon dioxide and methane fluxes in drained tropical peat before and after hydrological restoration, Ecology, 89, 3503-3514, 2008. 
Jauhiainen, J., Hooijer, A., and Page, S. E.: Carbon dioxide emissions from an Acacia plantation on peatland in Sumatra, Indonesia, Biogeosciences, 9, 617-630, doi:10.5194/bg-9-617-2012, 2012a.

Jauhiainen, J., Silvennoinen, H., Hämäläinen, R., Kusin, K., Limin, S., Raison, R. J., and Vasander, H.: Nitrous oxide fluxes from tropical peat with different disturbance history and management, Biogeosciences, 9, 1337-1350, doi:10.5194/bg-9-13372012, 2012b.

Jesus, E. C., Marsh, T. L., Tiedje, J. M., and Moreira, F. M. S.: Changes in land use alter the structure of bacterial communities in Western Amazon soils, ISME J., 3, 1004-1011, 2009.

Kanokratana, P., Uengwetwanit, T., Rattanachomsri, U. Bunterngsook, B., Nimchua, T., Tangphatsornruang, S., Plengvidhya, V., Champreda, V., and Eurwilaichitr, L.: Insights into the Phylogeny and Metabolic Potential of a Primary Tropical Peat Swamp Forest Microbial Community by Metagenomic Analysis, Microb. Ecol., 61, 518-528, 2011.

Katoh, K., Asimenos, G., and Toh, H.: Multiple alignment of DNA sequences with MAFFT, Methods Mol. Biol., 537, 39-64, 2009.

Kent, A. D., Smith, D. J., Benson, B. J., and Triplett, E. W.: WebBased Phylogenetic Assignment Tool for Analysis of Terminal Restriction Fragment Length Polymorphism Profiles of Microbial Communities, Appl. Environ. Microb., 11, 6768-6776, 2003.

Kim, S-Y., Freeman, C., Fenner, N., and Kang, H.: Functional and structural responses of bacterial and methanogen communities to 3 -year warming incubation in different depths of peat mire, Appl. Soil Ecol., 57, 23-30, 2012.

Kool, D. M., Buurman, P., and Hoekman, D. H.: Oxidation and compaction of a collapsed peat dome in Central Kalimantan, Geoderma, 137, 217-225, 2006.

Kruskal, J. B.: Multidimensional scaling by optimizing a goodness of fit to a nonmetric hypothesis, Psychometrics, 29, 1-28, 1964.

Lahde, E.: Biological activity in some natural and drained peat soils with special reference to oxidation-reduction conditions, Acta Forestalia Fennica, 94, 1-69, 1969.

Lee, S. S., Shin, K. J., Kim, W. Y., Ha, J. K., and Han, I. K.: The rumen ecosystem: as a fountain source of noble enzymes - review, Asian Austral. J. Anim., 12, 988-1001, 1999

Lee, Y. J., Narasimhan, K., and Swarup, S.: Enhancement of PlantMicrobe Interactions using Rhizosphere Metabolomics-Driven Approach and its Application in the Removal of Polychlorinated Biphenyls, in: Molecular Microbial Ecology of the Rhizosphere: Volume 2, edited by: de Bruijn, F. J., John Wiley \& Sons, Inc., USA, Chapter 114, 1191-1198, 2013.

Lefebvre, O., Nguyen, T. T., Al-Mamun, A., Chang, I. S., and Ng, H. Y.: T-RFLP reveals high $\beta$-Proteobacteria diversity in microbial fuel cells enriched with domestic wastewater, J. Appl. Microbiol., 109, 839-850, 2010.

Legendre, P. and Legendre, L.: Numerical Ecology (2nd English Edn.) Elsevier Science BV, Amsterdam, 1998.

Marilley, L., Vogt, G., Blanc, M., and Aragno, M.: Bacterial diversity in the bulk soil and rhizosphere fractions of Lolium perenne and Trifolium repens as revealed by PCR restriction analysis of 16 S rDNA, Plant Soil, 198, 219-224, 1998.

McLatchey, G. P. and Reddy, K. R.: Regulation of organic matter decomposition and nutrient release in a wetland soil, J. Environ. Qual., 27, 1268-1274, 1998.
Meimei, C., Baodong, C., and Petra, M.: Plant growth and soil microbial community structure of legumes and grasses grown in monoculture or mixture, J. Environ. Sci., 20, 1231-1237, 2008.

Melling, L., Hatano, R., and Goh, K. J.: Soil $\mathrm{CO}_{2}$ flux from three ecosystems in tropical peatland of Sarawak, Malaysia, Tellus B, 57, 1-11, 2005.

Miettinen, J. and Liew, S. C.: Degradation and development of peatlands in Peninsular Malaysia and in the islands of Sumatra and Borneo since 1990, Land Degrad. Dev., 21, 285-296, 2010.

Miettinen, J., Hooijer, A., Shi, C., Tollenaar, D., Vernimmen, R., Liew, S. C., Malins, C., and Page, S. E.: Extent of industrial plantations on Southeast Asian peatlands in 2010 with analysis of historical expansion and future projections, GCB Bioenergy, 4, 908-918, 2012a.

Miettinen, J., Hooijer, A., Wang, J., Shi, C., and Liew, S. C.: Peatland degradation and conversion sequences and interrelations in Sumatra, Reg. Environ. Change, 12, 729-737, 2012 b.

Moore, S., Evans, C. D., Page, S. E., Garnett, M. H., Jones, T. G., Freeman, C., Hooijer, A., Wiltshire, A. J., Limin, S. H., and Gauci, V.: Deep instability of deforested tropical peatlands revealed by fluvial organic carbon fluxes, Nature, 493, 660-664, 2013.

Murdiyarso, D., Hergoualc'h, K., and Verchot, L. V.: Opportunities for reducing greenhouse gas emissions in tropical peatlands, $\mathrm{P}$. Natl. Acad. Sci. USA, 107, 19655-19660, 2010.

Nazaries, L., Pan, Y., Bodrossy, L., Baggs, E. M., Millard, P., Murrell, J. C., and Singh, B. K.: Microbial regulation of biogeochemical cycles: evidence from a study on methane flux and land-use change, Appl. Environ. Microb., 79, 4031-4040, 2013.

Neff, J. C., Harden, J. W., and Gleixner, G.: Fire effects on soil organic matter content, composition, and nutrients in boreal interior Alaska, Can. J. Forest Res., 35, 2178-2187, 2005.

Nocker, A., Burr, M., and Camper, A. K.: Genotypic Microbial Community Profiling: A Critical Technical Review, Microb. Ecol., 54, 276-289, 2007.

Nold, S. C., Zhou, J., Devol, A. H., and Tiedje, J. M.: Pacific Northwest Marine Sediments Contain Ammonia-Oxidizing Bacteria in the $\beta$ Subdivision of the Proteobacteria. Appl. Environ. Microb., 66, 4532-4535, 2000.

Nybroe, O., Jorgensen, P. E., and Henze, M.: Enzyme-activities in waste-water and activated-sludge, Water Res., 26, 579-584, 1992.

Ollivier, J., Towe, S., Bannert, A., Hai, B., Kastl, E.-M., Meyer, A., Su, M. X., Kleineidam, K., and Schloter, M.: Nitrogen turnover in soil and global change, FEMS Microbiol. Ecol., 78 3-16, 2011.

Opelt, K., Berg, C., Schonmann, S., Eberl, L., and Berg, G.: High specificity but contrasting biodiversity of Sphagnum-associated bacterial and plant communities in bog ecosystems independent of the geographical region, ISME J., 1, 502-516, 2007.

Pagano, M. C., Scotti, M. R., and Cabello, M. N.: Effect of the inoculation and distribution of mycorrhizae in Plathymenia reticulata Benth under monoculture and mixed plantation in Brazil, New Forest, 38, 197-214, 2009.

Page, S. E., Siegert, F., Rieley, J. O., Boehm, H. D. V., Jaya, A., and Limin, S.: The amount of carbon released from peat and forest fires in Indonesia during 1997, Nature, 420, 61-65, 2002. 
Page, S. E., Rieley, J. O., and Banks, C. J.: Global and regional importance of the tropical peatland carbon pool, Glob. Change Biol., 17, 798-818, 2011.

Palmer, K. and Horn, M. A.: Actinobacterial nitrate reducers and proteobacterial denitrifiers are Abundant in $\mathrm{N}_{2} \mathrm{O}$-Metabolizing Palsa Peat, Appl. Environ. Microb., 78, 5584-5596, 2012.

Parab, G. S., Rao, R., Lakshminarayanan, S., Bing, Y. V., Moochhala, S. M., and Swarup, S.: Data-driven optimization of metabolomics methods using rat liver samples, Anal. Chem., 81, 1315-1323, 2009.

Peralta, A. L., Ludmer, S., and Kent, A. D.: Hydrologic history influences microbial community composition and nitrogen cycling under experimental drying/wetting treatment, Soil Biol. Biochem., 66, 29-37, 2013.

Philippot, L., Piutti, S., Martin-Laurent, F., Hallet, S., and Germon, J. C.: Molecular Analysis of the Nitrate-Reducing Community from Unplanted and Maize-Planted Soils, Appl. Environ. Microb., 68, 6121-6128, 2002.

Posa, M. R. C., Wijedasa, L. S., and Corlett, R. T.: Biodiversity and conservation of tropical peat swamp forests, BioScience, 61, 4957, 2011.

Putten, W. H. V.: Climate Change, Aboveground-Belowground Interactions, and Species' Range Shifts, Annu. Rev. Ecol. Evol. Syst., 43, 365-383, 2012.

Rasche, F., Knapp, D., Kaiser, C., Koranda, M., Kitzler, B., Zechmeister-Boltenstern, S., Richter, A., and Sessitsch, A.: Seasonality and resource availability control bacterial and archaeal communities in soils of a temperate beech forest, ISME J., 5, 389-402, 2011.

Reuben, S., Chua, C. L., Fam, K. D., Thian, Z. Y., Kang, M. K., and Swarup, S.: Bacterial diversity on different surfaces in urban freshwater, Water Sci. Technol., 65, 1869-1874, 2012.

Reynolds, W. D. and Clarke, T. G.: Soil sampling and methods of analysis, CRC Press, Taylor and Francis group, Boca Raton, FL, USA, 2008.

Schmaltz, J.: NASA Earth Observatory, available at: http: //earthobservatory.nasa.gov/IOTD/view.php?id=81431, last access: July 2013

Shepard, R. N.: The analysis of proximities: multidimensional scaling with an unknown distance function: parts I and II, Psychometrics, 27, 125-140 and 219-246, 1962.

Shyu, C., Soule, T., Bent, S. J., Foster, J. A., and Forney, L. J.: MiCA: A Web-Based Tool for the Analysis of Microbial Communities Based on Terminal-Restriction Fragment Length Polymorphisms of 16S and 18S rRNA Genes, Microb. Ecol., 53, 562570,2007
Sinsabaugh, R. L., Weiland, T., and Linkins, A. E.: Enzymic and molecular analysis of microbial communities associated with lotic particulate organic matter, Freshwater Biol., 28, 393-404, 1992.

Tamura, K., Peterson, D., Peterson, N., Stecher, G., Nei, M., and Kumar, S.: MEGA5: molecular evolutionary genetics analysis using maximum likelihood, evolutionary distance, and maximum parsimony methods, Mol. Biol. Evol., 28, 2731-2739, 2011.

Tveit, A., Schwacke, R., Svenning, M. M., and Urich, T.: Organic carbon transformations in high-Arctic peat soils: key functions and microorganisms, ISME J., 7, 299-311, 2013.

Wang, Y., Marschner, P., and Zhang, F.: Phosphorus pools and other soil properties in the rhizosphere of wheat and legumes growing in three soils in monoculture or as a mixture of wheat and legume, Plant Soil, 354, 283-298, 2012.

Wardle, D. A., Verhoef, H. A., and Clarholm, M.: Trophic relationships in the soil microfood-web: predicting the responses to a changing global environment, Glob. Change Biol., 4, 713-727, 1998.

Wardle, D. A., Bardgett, R. D., Klironomos, J. N., Setälä, H., Putten, W. H. V., and Wall, D. H.: Ecological Linkages Between Aboveground and Belowground Biota, Science, 304, 1629-1633, 2004

Wilmotte, A., Vander, A. G., and DeWachter, R.: Structure of the 16S ribosomal RNA of the thermophilic cyanobacterium Chlorogloeopsis HTF ("Mastigocladus laminosus HTF") strain PCC7518, and phylogenetic analysis, FEBS Lett., 3, 96-100, 1993.

Xiong, J., Wu, L., Tu, S., Nostrand, J. D. V., He, Z., Zhou, J., and Wang, G.: Microbial Communities and Functional Genes Associated with Soil Arsenic Contamination and the Rhizosphere of the Arsenic-Hyperaccumulating Plant Pteris vittata L, Appl. Environ. Microb., 76, 7277-7284, 2010.

Yu, S. and Ehrenfeld, J. G: Relationships among plants, soils and microbial communities along a hydrological gradient in the New Jersey Pinelands, USA, Annals Bot., 105, 185-196, 2010.

Zarea, M. J., Ghalavand, A., Goltapeh, E. M., Rejali, F., and Zamaniyan, M.: Effects of mixed cropping, earthworms (Pheretima sp.), and arbuscular mycorrhizal fungi (Glomus mosseae) on plant yield, mycorrhizal colonization rate, soil microbial biomass, and nitrogenase activity of free-living rhizosphere bacteria, Pedobiologia 52, 223-235, 2009.

Zhong, W., Gu, T., Wang, W., Zhang, B., Lin, X., Huang, Q., and Shen, W.: The effects of mineral fertilizer and organic manure on soil microbial community and diversity, Plant Soil, 326, $511-$ $522,2010$.

Zhou, J.: Microarrays for bacterial detection and microbial community analysis, Curr. Opin. Microbiol., 6, 288-294, 2003. 